\title{
Mapping method in research of drug crime regional criminological features (Ukraine taken as an example)
}

\author{
Andriy Babenko ${ }^{1}$, Ruslan Tarasenko ${ }^{1}$, and Oleksandr Ostrohliadov ${ }^{2}$ \\ ${ }^{1}$ Odessa State University of Internal Affairs, Odessa, Ukraine \\ ${ }^{2}$ Ministry of Internal Affairs of Ukraine, Kiev, Ukraine
}

\begin{abstract}
General national average drug crime rates on which the contemporary criminological theory and practice is based do not adequately reflect regional peculiarities in the field of illicit drug trafficking as they level high quality/quantity parameters in some areas and their lower values in others. Still, consideration of only national totals in organization of crime counteraction leads to incomplete information, neglecting its negative trends in certain areas, thus, causing aberration of the actual drug crime situation and using improper countermeasures. Under such circumstances the state law enforcement agencies do not operate preemptively against the illicit drug trafficking, do not contain in due time outbreaks of drug crime in certain areas- crime donors, and, as a result, the efficiency of steps aimed at drug addiction prevention as well as crime limitation in total becomes substantively deteriorated. Criminological mapping method enables the territorial police divisions to monitor existing criminological situation, inform the public and other law enforcement agencies on trends and locations of drug crime expansion, and reveal the most affected areas to be able to react promptly to crime pattern changes in regions. The application of this method enabled the evident demonstration of the fact that in Ukraine the Eastern and Southern areas were most affected by drug crime, wherein the affection factor in this part is twice higher than general national value.
\end{abstract}

Key words: drug crime, mapping method, regional criminological features.

\section{Introduction}

Drug addiction and related drug crimes today are among the most complex and most dangerous social problems of humanity, whose global character is confirmed by many negative facts. Thus, usage of drugs, production and cultivation of illegal substances and trade affect majority of countries in the world, devastatingly affecting public health, development and security of both industrialized and developing countries [1]. Drug dollars, which are flooding into the most powerful world banks, as evidenced, in particular, by the surmounting the crisis' paths of the financial world crisis of 2008-2009 [2, 3], deplete the economy of creation and development. According to expert estimates, the world drug trafficking is about $\$ 800$ billion, which can only be compared with the impact on the world oil and gas economy [4]. Drug trafficking continues to be the most lucrative form of business for criminals worldwide. Drug trafficking flows have global dimensions linking regions and continents [5]. Criminal groups have a high level of organization, as they have good equipment, using the latest information and communication technologies [6].

Additionally, specialists in the field of combating drugs have calculated that 28 million years of healthy life (premature mortality and disability) are lost annually through drug use, 
and another 17 million are lost due to illnesses that arise and develop because of these substances using $[7,8]$. The disaster scale is convincingly illustrated by the fact of estimated $1 / 4$ of a billion people, or about $5 \%$ of the global adult population, used drugs at least once in year (2015) [9-11].

As noted in the World Drug Report 2018, three tendencies have recently become apparent in the sphere of illicit drug trafficking: first, the so-called opiate crisis (the number of deaths caused by opiate use is $76 \%$ of all death cases, with the use of narcotic substances); secondly, the rising consumption of prescription drugs (87.0 tons of pharmaceutical opiates have been withdrawn); thirdly, record levels of heroin and cocaine production (it reached a peak and amounted approximately 1.410 tons and 87.0 tons per year respectively) $[12,13]$.

Thus, drug addiction [14, p. 351-352], as a negative social phenomenon, is, firstly, characterized by dynamism, since its movement takes place all over the world, quickly adapting to the new conditions associated with complications in running this business through active opposition to society, and secondly, has the ability to integrate well into the world economy (legalizing drug money, engaging in labor trafficking) and even influencing the political situation in some countries; thirdly, it is characterized by the property of certain geographical area structuring (forming the drugs production, organizing drug trafficking (their transportation) to markets, recruiting new substance consumers, which become soon drug addicts, serves as the basis for organized international criminality).

Ukraine plays a prominent role in the world drug trafficking. After all, it is, firstly, due its advantageous geographical position, in the chain of so-called Drug Silk Road; secondly, favorable climatic conditions make our country a producer of herbal drugs for the domestic and foreign markets with the simultaneous development of the production of synthetic drugs; thirdly, Ukraine is becoming louder about itself as a powerful market for these substances. Therefore, the considered issue of illicit drug trafficking is, of course, relevant for Ukraine, its dynamism, integration and structuring can be represented using the method of cartography, which allows creating maps of criminal acuteness of drug criminality in different country's regions, with the most dangerous identified zones, to point out correlations between different factors that cause crime. It can help to monitor the systematic criminal activity conduct, to carry out criminological analysis of the current situation by territorial police units, promptly reacting to changes in regions' crime rate and informing public and other state bodies about tendencies and geography of drug crimes spreading, etc.

The research aim is to reveal the possibilities and determine the effectiveness of criminological mapping method on the example of the analysis of current tendencies and regional criminological peculiarities of drug crimes in different regions of Ukraine, which seems necessary for two reasons. First, the national average indicators of drug offenses do not fully take into account the regional specificity of the latter, since these indicators offset high quantitative and qualitative parameters in some regions and low indicators in others. Secondly, taking into account only the national indicators in the organization of counteracting drug crimes leads to incompleteness of information. Under such conditions, the state law enforcement system does not work to prevent illicit drug trafficking, does not timely locate the cells of its outbreak in separate regions - "donors" of crime, as a result of which there is a significant decrease in the effectiveness of measures aimed at preventing drug addiction.

\section{Methods}

The methodological basis for conducting research of the possibilities of cartography in identifying of the criminological peculiarities of drug crimes in Ukraine is: 1) the official statistics of the Department of Information and Analytical Support of the Ministry of Internal 
Table 1. Levels and proportion of crimes in the field of illicit drug trafficking (2011-2017).

\begin{tabular}{|l|l|l|l|l|l|l|l|}
\hline Parameters & $\mathbf{2 0 1 1}$ & $\mathbf{2 0 1 2}$ & $\mathbf{2 0 1 3}$ & $\mathbf{2 0 1 4}$ & $\mathbf{2 0 1 5}$ & $\mathbf{2 0 1 6}$ & $\mathbf{2 0 1 7}$ \\
\hline $\begin{array}{l}\text { Quantity of } \\
\text { crimes }\end{array}$ & 53206 & 45322 & 33180 & 30045 & 25325 & 22217 & 27912 \\
\hline $\begin{array}{l}\text { Coefficient of } \\
\text { criminal } \\
\text { intensities }\end{array}$ & 116 & 99 & 72 & 70 & 59 & 52 & 68 \\
\hline $\begin{array}{l}\text { Proportion } \\
(\%)\end{array}$ & 10.3 & 10.2 & 5.9 & 5.7 & 4.5 & 3.8 & 5.3 \\
\hline
\end{tabular}

Affairs of Ukraine and the Unified Register of Pre-trial Investigations and Informational and Analytical Work of the General Prosecutor's Office of Ukraine; 2) analytical materials of the UNODC; 3) demonstration of quantitative and qualitative indicators of drug crimes on geographical map; 4) tabular method that performs an additional explanatory function during the analysis of the parameters of the phenomenon under consideration. The empirical and statistical data are summarized and analyzed using the capabilities of descriptive statistics; 5) method for calculating the correlation between the phenomena of K. Pearson. Calculations and mapping are done using Adobe Photoshop CS6, Microsoft Excel 2016, Microsoft Word 2016 and QuickMap.

\section{Results}

The development of the method of criminological cartography [15-22] can be considered as one of the strategic directions in improving the information and analytical support of law enforcement agencies work of any state. Criminological cartography and regional criminological analysis contribute to the effective organization of preventing of illicit drug trafficking, thus envisaging rational use of forces and means of counteraction in the work of law-enforcement bodies. Such a distribution of forces and means must be carefully planned, differentiated and adapted to the local conditions of a particular territorial system.

The essence of criminological cartography lies in the hypothesis of the proposed objective and tasks of the differentiated spatial (rating, correlation, etc.) analysis of drug crimes in accordance with predefined and calculated parameters of the main indicators of this crime (its level, structure, intensity, dynamics, etc.) depending on the territory of analyzed crimes with the drawing of relevant data on thematic maps [23].

Although, according to the Ukrainian Monitoring and Drug and Drug Center of the Ministry of Health of Ukraine, as of 01.01.2017, there were 694928 people under observation in the country with mental and behavioral disorders due to psychoactive substances using, and 115,170 people were registered for only one year, who, for the first time in their life, have been diagnosed with mental and behavioral disorders associated with the use of psychic substances [24, p. 71.] Official statistics of law enforcement agencies indicate a significant improvement in the situation in the area of counteraction to illicit drug trafficking (Table 1).

It followed from the given data that since 2013 the registration of detected drug crimes has decreased almost twice. The intensity of crimes in this category also shows similar trends. There was a noticeable decrease in the proportion of drug crimes [25-32]. This situation is the result of deterioration of the work of law enforcement agencies, which is due to: firstly, miscalculations in law enforcement reform, in particular, in the field of staff policy (dismissal of experienced workers, liquidation of territorial units for combating illicit drug trafficking, shortcomings in training staff for law enforcement agencies, etc.); secondly, the development 


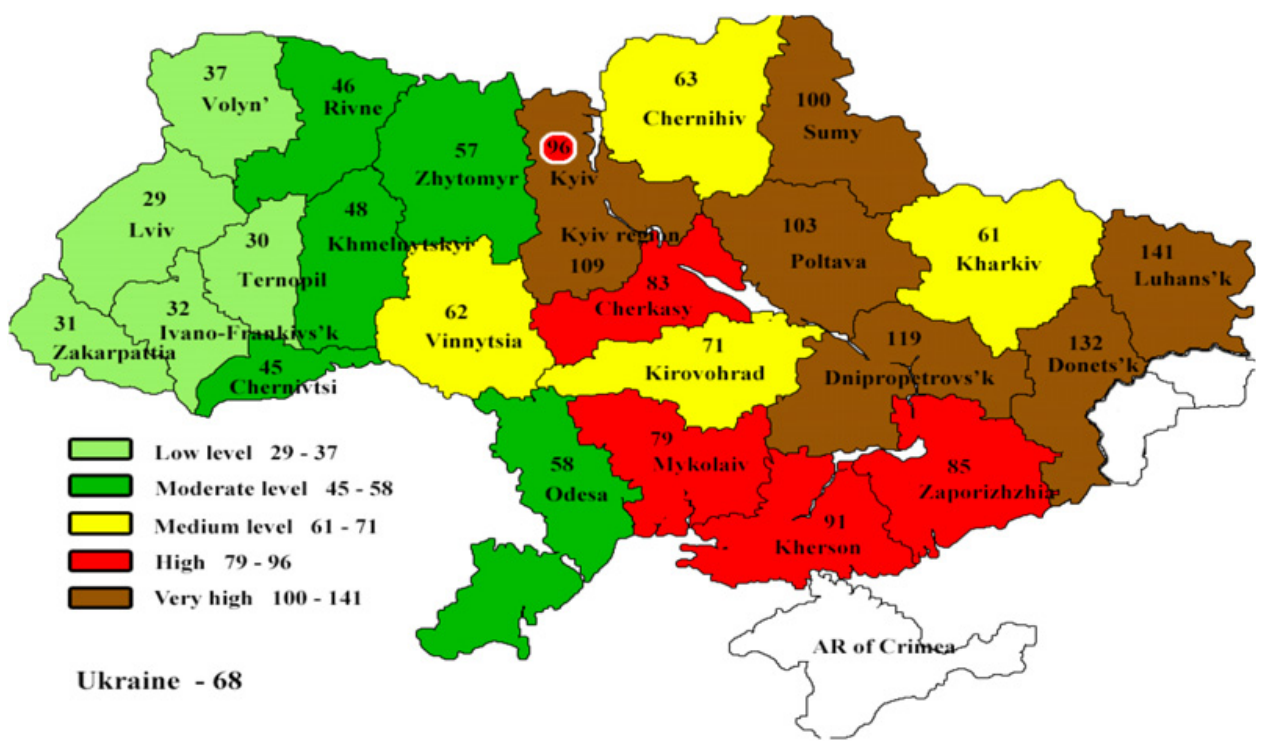

Map 1. Geography of the drug criminality intensity recorded in the regions of Ukraine (2017).

of new forms and types of illegal activities by drug offenders, excluding the direct contact of drug seller with drug buyer (for example, drug trafficking through the Internet); thirdly, using the latest methods of advertising and distribution of drugs; fourthly, with careful concealment of illegal activity and the avoidance of responsibility for the committed crimes, etc. The following were the logical consequences of this: 1) increase of drug crimes, expansion of spheres of influence, increase in the market and expansion of the offer of different drugs, involvement of new groups of population; 2) tardy reaction of law enforcement agencies to counteract drug criminals. The decrease in the efficiency of work is also explained by the lack of a scientifically based approach of law enforcement agencies to the distribution of forces and means to counter drug crimes, taking into account its territorial features; disregarding the crime specifics in the context of some settlements, etc.

With the help of the method of cartography, five groups of regions with different levels of drug criminality intensity (smear) can be identified (map 1).

The highest concentration of crimes in the area of illicit drug trafficking is seen in the eastern and southern regions of Ukraine, which make up a group of territories with very high and high levels of this type of crime (on average, from 79 to 141 crimes per 100,000 of population). Consequently, these territories can be designated as belonging to a negative crime zone, characterized by high and very high coefficients of drug criminality intensity. The middle (transitional) criminal zone includes two central, one northern and eastern regions of Ukraine (Kirovograd, Vinnitsa, Chernihiv and Kharkiv), in which there are 61-71 drug crimes per 100 thousand population. The western regions of Ukraine and one southern Odesa region are part of a relatively positive crime zone, characterized by low and moderate indicators of criminal prevalence (an average of 29-58 crimes per 100 thousand of population). Consequently, the method of cartography makes it possible to state that regional features of drug crime from the point of view of its concentration in the country's regions are very unequal, indicating significant differences in the levels of criminal prevalence of territories up to five times. 
Table 2. Level and proportion of crimes in the area of illicit drug trafficking committed in some regions of Ukraine (2017).

\begin{tabular}{|c|c|c|c|c|c|}
\hline parameters & $\begin{array}{c}\text { Ukraine } \\
\text { as a whole }\end{array}$ & $\begin{array}{l}\text { Dniepro- } \\
\text { petrovs'k }\end{array}$ & Kharkiv & Odesa & L'viv \\
\hline $\begin{array}{l}\text { Total quantity of } \\
\text { crimes }\end{array}$ & 523911 & 44343 & 34986 & 32576 & 27526 \\
\hline $\begin{array}{l}\text { Drug crimes } \\
\text { quantity }\end{array}$ & 29010 & 3832 & 1647 & 1379 & 732 \\
\hline $\begin{array}{l}\text { Proportion } \\
(\%)\end{array}$ & 5.5 & 8.6 & 4.7 & 4.2 & 2.7 \\
\hline
\end{tabular}

Table 3. The level and proportion of crimes in the area of drug trafficking committed in some regions of Ukraine by type of drug crimes (2017).

\begin{tabular}{|c|c|c|c|c|c|c|}
\hline $\begin{array}{l}\text { Kegion } \\
\text { cases }\end{array}$ & 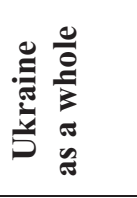 & 营 & 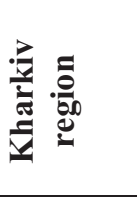 & 窇 & 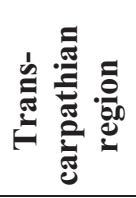 & $\frac{5}{\partial}$ \\
\hline Total & 29010 & 1379 & 1647 & 654 & 396 & 386 \\
\hline $\begin{array}{l}\text { Art. } 305 \text { (drug } \\
\text { smuggling) }\end{array}$ & $\begin{array}{c}251 \\
(0.86 \%)\end{array}$ & $\begin{array}{c}14 \\
(1 \%)\end{array}$ & $\begin{array}{c}54 \\
(3.3 \%)\end{array}$ & $\begin{array}{c}35 \\
(5.35 \%)\end{array}$ & $\begin{array}{c}19 \\
(5 \%)\end{array}$ & $\begin{array}{c}25 \\
(7 \%)\end{array}$ \\
\hline $\begin{array}{l}\text { Art. } 307 \text { (drug } \\
\text { production, } \\
\text { distribution and } \\
\text { industry) }\end{array}$ & $\begin{array}{c}5029 \\
(17.3 \%)\end{array}$ & $\begin{array}{c}226 \\
(16.4 \%)\end{array}$ & $\begin{array}{c}338 \\
(20.5 \%)\end{array}$ & $\begin{array}{c}161 \\
(24.6 \%)\end{array}$ & $\begin{array}{c}117 \\
(30 \%)\end{array}$ & $\begin{array}{l}157 \\
(40 \%)\end{array}$ \\
\hline $\begin{array}{l}\text { Art. } 309 \text { (drug } \\
\text { storage without } \\
\text { industry purpose) }\end{array}$ & $\begin{array}{c}20071 \\
(69.2 \%)\end{array}$ & $\begin{array}{c}958 \\
(69.4 \%)\end{array}$ & $\begin{array}{c}1092 \\
(66.3 \%)\end{array}$ & $\begin{array}{c}385 \\
(58.9 \%)\end{array}$ & $\begin{array}{c}194 \\
(48 \%)\end{array}$ & $\begin{array}{c}141 \\
(36 \%)\end{array}$ \\
\hline $\begin{array}{l}\text { Art. } 310 \text { (illegal } \\
\text { cultivation of } \\
\text { drug plants) }\end{array}$ & $\begin{array}{l}2017 \\
(6.9 \%)\end{array}$ & $\begin{array}{c}92 \\
(6.67 \%)\end{array}$ & $\begin{array}{c}64 \\
(3.9 \%)\end{array}$ & $\begin{array}{c}55 \\
(8.5 \%)\end{array}$ & $\begin{array}{c}51 \\
(13 \%)\end{array}$ & $\begin{array}{l}33 \\
(9 \%)\end{array}$ \\
\hline $\begin{array}{l}\text { Art. } 310 \text { (illegal } \\
\text { cultivation of } \\
\text { drug plants) }\end{array}$ & $\begin{array}{l}2017 \\
(6.9 \%)\end{array}$ & $\begin{array}{c}92 \\
(6.67 \%)\end{array}$ & $\begin{array}{c}64 \\
(3.9 \%)\end{array}$ & $\begin{array}{c}55 \\
(8.5 \%)\end{array}$ & $\begin{array}{c}51 \\
(13 \%)\end{array}$ & $\begin{array}{l}33 \\
(9 \%)\end{array}$ \\
\hline
\end{tabular}

Tabular method is useful, for example, when analyzing such an important indicator of drug crimes' state as its structure. The regional structure of the analyzed crime differs from the corresponding national indicators. This can be clearly seen in the Table 2 (the example of separate regions of Ukraine).

The data presented in the table indicate significant differences in the proportion of drug crimes in the structure of all offenses in region. Thus, with the national average specific gravity of drug crimes in $5.5 \%$, the share of drug crimes in the L'viv region is $2.7 \%$; in Odesa $-4.2 \%$; in Kharkiv $-4.7 \%$, while in Dnipropetrovs'k $-8.6 \%$. This gives grounds for conclusion that the unequal pressure of specific crimes on the regional crime situation is common, for example, in the Dnipropetrovs'k region the share of drug crimes in the structure of all crimes is three times higher than in L'viv. Regarding, in a nutshell, the domestic regional structure of drug crimes, here we also fixed significant regional features (Table 3). 


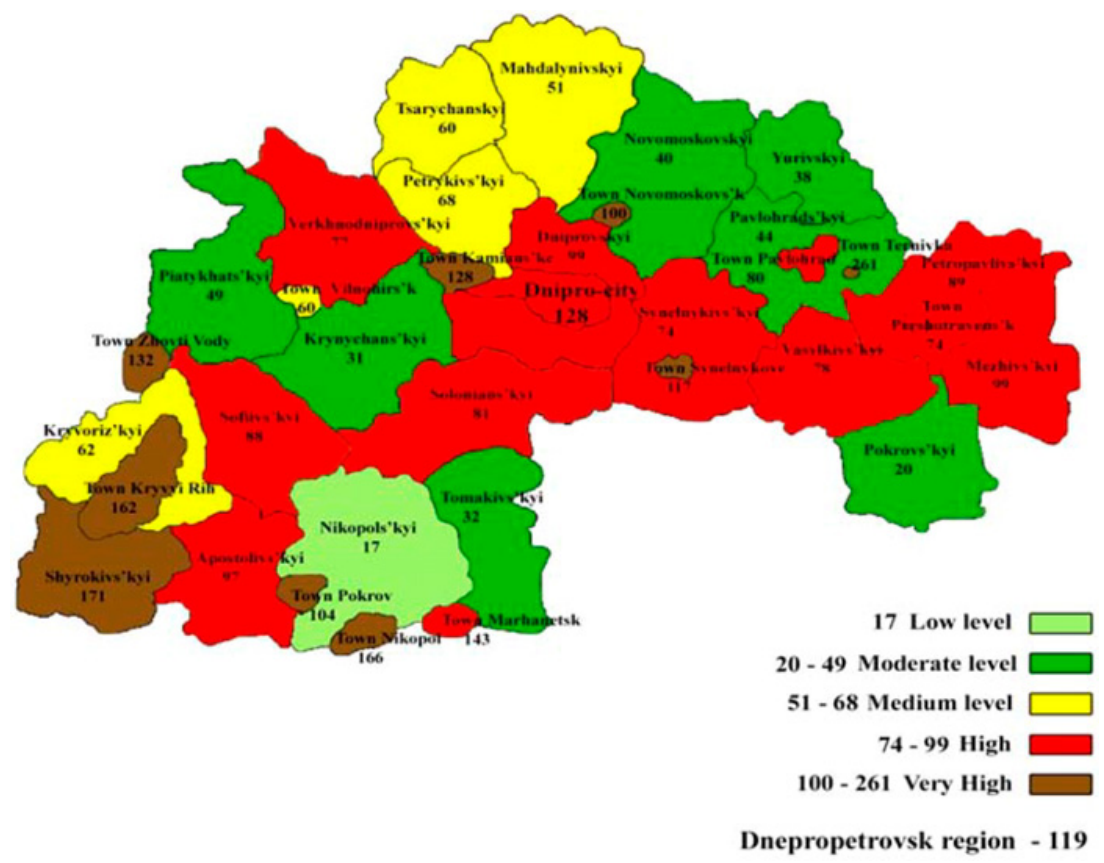

Map 2. Geography of drug criminality intensity per 100 thousand of population in towns and non-urban areas of Dnipropetrovs'k region of Ukraine (2017).

Table 4. Territorial distribution of drug criminality in towns and non-urban areas by the example of some regions of Ukraine (2017).

\begin{tabular}{|l|c|c|c|c|}
\hline $\begin{array}{l}\text { parameters /quantitative } \\
\text { indicators }\end{array}$ & Dnipro & Kharkiv & Odesa & L'viv \\
\hline in the region & 3833 & 1647 & 1379 & 732 \\
\hline in all towns of the region & $3282(85.6 \%)$ & $1196(72.6 \%)$ & $958(69.5 \%)$ & $455(62.2 \%)$ \\
\hline in a regional town & $1283(33.5 \%)$ & $1068(64.8 \%)$ & $734(53.2 \%)$ & $327(44.7 \%)$ \\
\hline in a small town of the region & $1999(52.1 \%)$ & $128(7.8 \%)$ & $224(16.3 \%)$ & $128(17.5 \%)$ \\
\hline in non-urban area & $551(14.4 \%)$ & $451(27.4 \%)$ & $421(30.5 \%)$ & $277(37.8 \%)$ \\
\hline
\end{tabular}

The analysis of regional criminological peculiarities of drug criminality in Ukraine is annexed with information on the geography of the internal intensity of the last for 100 thousand of population and this intensity rating in the context of separate several regions' towns (Maps 2, 3 and Tables 4, 5).

Thus, according to the local conditions of reproduction of crime and the attractiveness of territories for drug crimes, the focus of prevention activities, for example, for a particularly large industrial Kharkiv region, should be concentrated in regional Kharkiv city, where $64.8 \%$ of all drug crimes in the region are committed. In Odesa region, prevention of crime should be organized primarily in Odesa city, having $53.2 \%$ of drug crimes, as well as in regional agricultural districts, where $30.5 \%$ of these offenses are committed respectively.

The pointed indicators show the extremely difficult situation in the sphere of illicit drug trafficking in the Dnipropetrovsk region. Significant part of its territory is occupied by a 


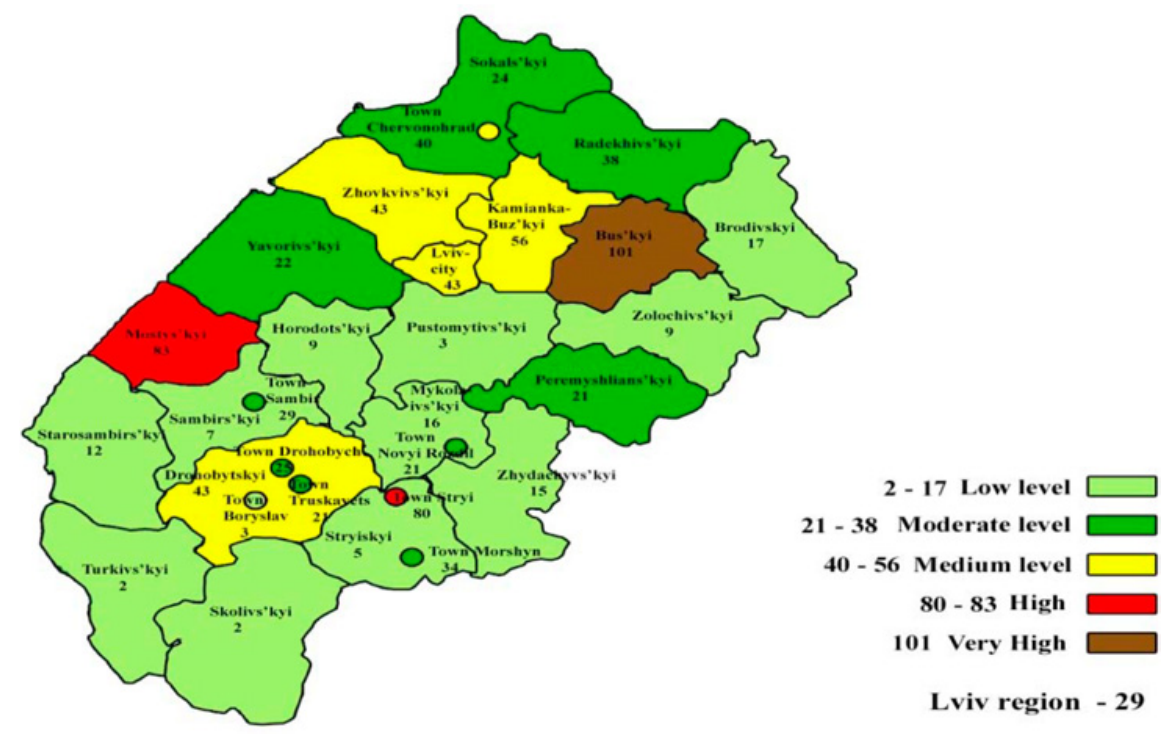

Map 3. Intensity geography of drug criminality per 100 thousand population in towns and non-urban areas of the L'viv region of Ukraine (2017).

Table 5. Rate of drug criminality intensity in towns and non-urban areas by the example of Dnipropetrovs'k and L'viv regions per 100 thousand of population (2017).

\begin{tabular}{|c|c|c|c|c|}
\hline 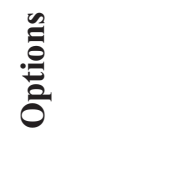 & 光 & 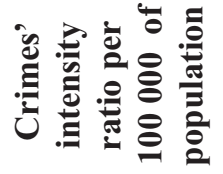 & 光 & 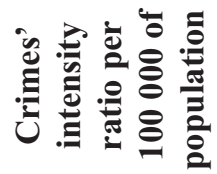 \\
\hline Rank & $\begin{array}{c}\text { Dnipropetrovs'k } \\
\text { region }\end{array}$ & 119 & L'viv region & 29 \\
\hline 1 & Ternivka town & 261 & Busk district & 101 \\
\hline 2 & Shyrokiv district & 171 & $\begin{array}{l}\text { Mostysky } \\
\text { district }\end{array}$ & 83 \\
\hline 3 & Nikopol town & 166 & Stryi town & 80 \\
\hline 4 & Kryvyi Rih town & 162 & $\begin{array}{c}\text { Kamianka- } \\
\text { Busky district }\end{array}$ & 56 \\
\hline 5 & Marhanetsk town & 143 & $\begin{array}{l}\text { Zhovkva } \\
\text { district }\end{array}$ & 43 \\
\hline 6 & Zhovti Vody town & 132 & $\begin{array}{l}\text { Drohobych } \\
\text { district }\end{array}$ & 43 \\
\hline 7 & Kamians'ke town & 128 & L'viv city & 43 \\
\hline 8 & Dnipro city & 128 & $\begin{array}{l}\text { Chervonohrad } \\
\text { town }\end{array}$ & 40 \\
\hline 9 & Synelnykove town & 117 & $\begin{array}{l}\text { Radekhiv } \\
\text { district }\end{array}$ & 38 \\
\hline 10 & Pokrov town & 104 & Morshyn town & 34 \\
\hline $\begin{array}{l}\text { In Ukraine } \\
\text { as a whole }\end{array}$ & \multicolumn{4}{|c|}{68} \\
\hline
\end{tabular}


Table 6. Correlation coefficients of the rate of registered theft and drug crimes in Ukraine, made by K. Pearson (2009-2017).

\begin{tabular}{|c|c|c|c|c|c|c|c|c|c|}
\hline \multirow[b]{2}{*}{ Options } & \multicolumn{9}{|c|}{ Periods } \\
\hline & ڤ్రે & $\stackrel{\ominus}{\bar{\nu}}$ & $\overline{\overline{\text { సे }}}$ & $\widetilde{\tilde{N}}$ & $\stackrel{m}{\stackrel{2}{\sim}}$ & $\underset{\bar{N}}{ \pm}$ & 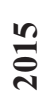 & 룰 & 공 \\
\hline 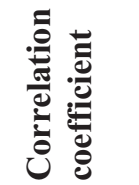 & 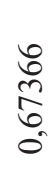 & $\begin{array}{l}\hat{2} \\
\hat{\infty} \\
0 \\
0 \\
0\end{array}$ & $\begin{array}{l}\tilde{n} \\
m \\
\infty \\
0 \\
0 \\
0\end{array}$ & $\begin{array}{l}\text { ర్ } \\
\text { ర్ర } \\
\text { : }\end{array}$ & 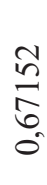 & $\begin{array}{l}\stackrel{1}{\hat{d}} \\
\text { : } \\
0\end{array}$ & $\begin{array}{l}\hat{\mathbb{N}} \\
\text { n. } \\
\text { o. }\end{array}$ & 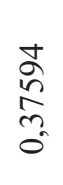 & $\begin{array}{l}n \\
\delta \\
0 \\
+ \\
0\end{array}$ \\
\hline
\end{tabular}

negative criminological group (63\% of the territory with an intensity of 74 to 261 drug crimes per 100 thousand of population), while L'viv region is dominated by relatively safe towns in terms of drug prevalence ( $72 \%$ of the territory with an intensity of 2 to 38 drug crimes per 100 thousand of population). In addition, in the ten most sensitive towns of Dnipropetrovs'k and L'viv regions, the town's domination tends to be a regional average, while territories with the highest parameters of drug criminality in the L'viv region (with an intensity of 80 to 101 drug crimes per 100,000 of population) are similar, with the lowest rates of the first ten towns of the Dnipropetrovs'k region (with an intensity of 104 to 117 drug crimes per 100 thousand of population). At the same time, the highest indicators of drug criminality intensity in the Dnipropetrovs'k region exceed several times similar data in the chosen region for comparing to the L'viv region [33], and in ten Dnipropetrovs'k region's towns the criminal drug offenses' level exceeds the national parameters from 2 to 4 times, while in L'viv only in the Busk district (with intensity coefficient of 101 crimes per 100 thousand of population) is 1.5 times higher than the average Ukrainian indicators (with intensity coefficient 68 crimes per 100 thousand of population).

\section{Discussion}

Further elaboration of regional features' methodology of crime in general and drug crime, in particular is needed. Indeed, in similar researches, the question, which appears in the geographical plan of the object for comparison, is not solved until now - whether it is the country as a whole or even several countries, or administrative territorial units of a separate country, or separate areas of one administrative - territorial unit. At the same time, we believe that the national experience of researching regional features of drug crimes through the method of cartography should be expanded with the analysis and comparison of the drug criminality situation in countries, which, for example, are connected with Ukraine by common border.

The controversial moment of the theoretical nature is the problem of regional criminology's formation as an independent area of research. If, according to regional criminology, it is nevertheless recognized as the right to be an independent direction of theoretical knowledge, then it is necessary to establish a line of conditional demarcation between the latter and the geography of crime.

It is also known that thefts and drug crimes are interrelated phenomena, since a significant proportion of thefts are committed by persons involved in drug trafficking and consumers of these substances. Their dependence is shown by the analysis of correlation dependencies, carried out by the method of calculating the correlation coefficient of K. Pearson. By 2015, there was a significant direct correlation between the intensity of theft and drug crimes, which 
had been established for many years. The decrease of this correlation coefficient in 2015 is likely to be the result of special units' liquidation aimed at combat drug trafficking in Ukraine the same year.

On the basis of the above mentioned, it is necessary to check the hypothesis of dependence of "violation" on correlation between thefts and drug criminality in 2015 and liquidation of special units which combat illicit drug trafficking both in Ukraine as a whole and in some regions.

\section{Conclusions}

The results of the study of regional criminological peculiarities of drug crimes in Ukraine with the help of the method of criminological cartography have made it possible to state that the regional peculiarities of drug crimes due to their concentration in those or other regions of the country indicate significant differences in the levels of criminal damage to territories up to five times. At the same time, the response of law enforcement agencies to drug crimes and other related offenses does not correspond to the real state of criminalization of society, because the power structures are based on insufficient knowledge of existing criminal situation. It is the result of failure to take into account the possibilities of modern technologies that allow drawing up maps of criminal damage of regions. The usage of this method allows us to step back from practice of leveling drug crimes' features in some regions of Ukraine. In this way, there is a real possibility to redistribute properly the powers of the state's law enforcement system in order to, firstly, work to advance the state of aggravation of drug situation in certain regions of country, and secondly, to work on operational location of its out-breaking cells.

\section{References}

[1] Drug prevention, treatment and care (Working towards evidence-based drug dependence treatment and care). Available: http://www.unodc.org/ westandcentralafrica/en/newrosenwebsite/drug-prevention-treatmentand-care/drug-prevention-treatment-and-care.html

[2] Drug money saved banks in global crisis, claims UN advisor. The Guardian. December 13 (2009). Available: https://oldimg1.ria.ru/beznarko_help/20130626/ 828973392.html

[3] Деньги от наркоторговли помогли банкам во время мирового кризиса, утверждает представитель ООН. InoPressa.ru. Декабрь 14 (2009)

[4] Доходы мирового наркобизнеса. Available: https://oldimg1.ria.ru/ beznarko_help/20130626/.html

[5] Drug Trafficking: a $\$ 32$ billion business affecting communities globally. Available: http://www . unodc.org/southasia/frontpage/2012/August/drugtrafficking-a-business-affecting-communities-globally.html

[6] Tendencies of drug trafficking in Russia in 2004. Moscow: Region. Representative Office of the United Nations Office on Drugs and Crime in Russia and Belarus (2005)

[7] Executive Summary Conclusions and Policy Implications. World Drug Report 2017. Vienna: UNODC (2017)

[8] Fact Sheet on Statistics and Trends in Illicit Drugs. Available: http://www. unodc.org/wdr2017/field/WDR17_Fact_sheet.pdf

[9] World Drug Report 2015, New York: United Nations (2015)

[10] World Drug Report 2016 / United Nations Office on Drugs and Crime, 2016. Vienna: United Nations Office on Drugs and Crime (2016) 
[11] Executive Summary Conclusions and Policy Implications. World Drug Report 2017. Vienna: UNODC (2017)

[12] Всемирный доклад о наркотиках 2018: опиоидный кризис, растущий уровень употребления рецептурных препаратов, рекордные уровни производства кокаина и героина. Available: http://www.eegyn. $\mathrm{com} / \mathrm{pdf} / W D R \_2018 \_P r e s s R e a l e a s e R U S . P D F$

[13] World Drug Report 2018: opioid crisis, prescription drug abuse expands; cocaine and opium hit record highs. Available: http://www.unodc.org/ unodc/en/frontpage/2018/June/world-drug-report-2018_opioid-crisisprescription-drug-abuse-expands-cocaine-and-opium-hit-recordhighs.html

[14] Большой юридический словарь / под. ред. А. Я. Сухарева, В. Е. Крутских. Москва: Инфра-М (2001)

[15] Бабенко А. М., Орещенко А. В. Можливості картографічних методів дослідження у інформаційно-аналітичному забезпеченні протидіы торгівлії людьми. Акт. пит. б-би з торгівлею людьми в умовах проведення антитерористичної операції (збройного конфлікту): зб. матеріалів міжнар. круглого столу. Київ: ВД «Дакор». С. $42-48$ (2017)

[16] Мальцев В. В., Болотова В. О. Картографування злочинності: історія розвитку. Девіантна поведінка: соціолог., психолог. та юрид. аспекти: матеріали наук.-практ. конф. (Харків, 10 квіт. 2010 р.). Харків: ХНУВС. C. 96-99 (2010)

[17] Bianchini Å., Sicurella S. Cases on Technologies for Teaching Criminology and Victimology: Methodologies and Practices. Hershey, New York: Information Science Reference (2009)

[18] Camilleri G., Lazerges Ñ. Atlas de la Criminalité en France. Mappemonde. 2, 6-9 (1992)

[19] Chainey S., Ratcliffe J. GIS and Crime Mapping. New York: John Wiley \& Sons (2005)

[20] Cunty C., Fussy F., Perez P. Geocriminologie, quand la cartographie permet aux geographes d'investir la criminologie. CyberGeo. Jul. (2007)

[21] Hill B., Paynich R. Fundamentals of Crime Mapping. London: Jones and Bartlett publishers (2014)

[22] Santos R.B. Crime Analysis With Crime Mapping. CA, USA: Sage Publications (2008).

[23] Бабенко А.М. Регіональна злочинність в Украйні: закономірності, детермінація та запобігання: дис. ... д-ра юрид. наук. Запоріжжя (2015)

[24] Національний звіт за 2017 рік щодо наркотичної ситуації в Україні (за даними 2016 року) Київ (2017)

[25] Стан та структура злочинності в Україні (2010-2011 pр.) 2017. http://mvs.gov.ua/mvs/control/main/ uk/publish/article/717134;14

[26] Єдиний звит про криминальни правопорушення за сичень-грудень 2017 року. Available: http://www.gp.gov.ua/ua/stst2011.html?dir_id= $112755 \&$ libid $=100820$

[27] Стан та структура злочинности в України за 2007 - по 20.11.2012 pp.: статистика МВС. Аваилабле: http://mvs.gov.ua

[28] Сдиний звит про криминальни правопорушення за 2013-2017 pр.: статистична информація. Available: http://www.gp.gov.ua

[29] Статистичний щорічник Украӥни за 2010 рік. Кийв: Август Трейд (2011) 
[30] Статистичний щорічник України за 2012 рік. Київ: Держаналїтнформ (2013)

[31] Статистичний щорічник України за 2013 рік. Київ: Держаналітінформ (2014)

[32] Статистичний щорічник Украӥни за 2016 рік. Київ: Держаналітінформ (2017)

[33] Бабенко А.М. Сучасний стан і тенденцї наркозлочинності, вбивств та самогубств у мистах і сільськіх районах України: криімінологічній вимір та запобігання. Наук. вісн. Днипропетр. держ. ун-ту внутр. справ: наук. журн. 1(91). С. 16-26 (2018) 